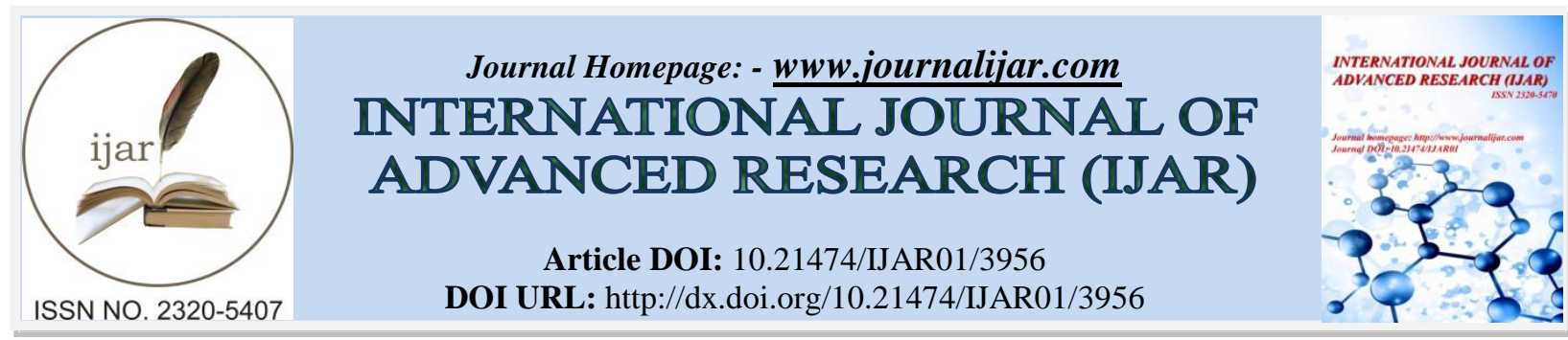

RESEARCH ARTICLE

\title{
SYNTHESIS AND STRUCTURAL CHARACTERIZATION OF SOME PHTHALAZIN-1(2H)-ONE URANYL NITRATE COMPLEX ANTICANCER.
}

M. A. EL-Hashash ${ }^{1}$, S. A. Rizk ${ }^{1 *}$, F.A. El-Bassiouny ${ }^{1}$, D. B. Guirguis ${ }^{1}$, L.A. Guirguis ${ }^{2}$ and S. M. Khairy ${ }^{2}$

1. Department of Organic Chemistry, Faculty of Science, University of Ain Shams ,Cairo, Egypt,

2. Department of reactor materials, nuclear material authority Egypt, Egypt

\section{Manuscript Info}

Manuscript History

Received: 16 February 2017

Final Accepted: 19 March 2017

Published: April 2017

\section{Abstract}

A new series of phthalazin-1(2H)-one complex and studying of the spectroscopic like FT-IR, 1H-NMR and HEPG-2 properties as application of complex The biological activity as antitumor. compound has an significant anticancer activity against human liver carcinoma cells HEPG-2 to the ligand and the determine the urinal nitrate complex Uo2(4-(3-chloro-4-methylphenyl)-1-oxophthalazin-2(1H)yl)acetate)2. (NO3) $)_{2} 6 . \mathrm{H}_{2} \mathrm{O} \quad 5$ are showing high cytotoxicity $48 \mathrm{ug} / \mathrm{ml}$ than the ligand 4-(3-chloro-4-methylphenyl)-1-oxophthalazin-2(1H)yl)acetate) as antitumor against a panel of human tumour cell lines HEPG-2 comparing with the other complex have urinal nitrate don't have any biological activity against human liver carcinoma .

Copy Right, IJAR, 2017,. All rights reserved.

\section{Introduction:-}

Studying of ligands and the metal complex has a very effective role in many area of chemistry application one of most important ligands is the heterocyclic compound containing $\mathrm{N}$-donor atom the interest of the ligands due to photo physical, biological and spectroscopic properties, phthalazine is one of azines which are potentially bidentate ligand that use to form metal complex, phthalazin-1 $(2 \mathrm{H})$-one are studied with many metal for example $\mathrm{Mn}, \mathrm{Fe}, \mathrm{Co}, \mathrm{Ni}, \mathrm{Cu}, \mathrm{Zn}, \mathrm{Cd}, \mathrm{Ir}, \mathrm{V}$ and $\mathrm{Ru} .{ }^{1-8}$ the main interest of the phthalazin-1(2H)-one complex due to the spectroscopic properties as an important application of complex and The biological activity as antitumor, hypotensive, antifungal and antimicrobial of this complex give the attention to be studded from many way ${ }^{7,9}$. the complexes of phthalazine with heavy metal play a very important role in forming organic light-emitting diodes (OlEDs) on of base of the forming due to founding $\mathrm{sp}^{2}$-hybird $\mathrm{N}$ in the ligand due to the spin-orbit of heavy-metal ions is phosphorescent complex's ${ }^{10-13}$ the complex with iridium is promising OLED for full color panel display ${ }^{8,14,15}$ the important of using phthalazine $\mathrm{BPPa}[1,4-\mathrm{bis}(\mathrm{phenyl)}$ phthalazine] in synthesis of dinuclear complexes due to the ability to forming metal-metal separation range from $2.550 \mathrm{~A}^{0}$ to $4.045 \mathrm{~A}^{0}{ }^{8}$, bdptz\{1,4-bis(2,2'dipyridylmethyl)phthalazine $\}$ and $\mathrm{Ph}_{4}$ bdptz \{1,4-bis[bis(6-phenyl-2-pyrdyl)methyl] phthalazine $\}$ is used to prepare dinuclear compounds with different transition metal ions as hydrophobic pocket ${ }^{16-20}$. N- donor ligands with urinal nitrate as complex give antitumor activity as complexes against a panel of human tumor cell lines (HT29: Haman colon adenocarcinoma cell line T47D human breast adenocarcinoma cell line), significant anticancer activity against Ehrlich ascites tumor cells ${ }^{21-29 .}$

Corresponding Author:- M. A. EL-Hashash.

Address:- Department of Organic Chemistry, Faculty of Science, University of Ain Shams ,Cairo, 


\section{Results and Discussion:-}

phthalazin-1(2H)-one molecule gives three donor sites two pyridine ring nitrogen's and carbonyl oxygen. As a poly dentate ligand the bonding may take place through the two ring nitrogen's or the carbonyl oxygen or both sites The frequency shifts on the vibrational bands of the metal complexes relative to those of free ligand molecule indicate clearly that the carbonyl oxygen of phthalazin- $1(2 \mathrm{H})$-one is involved in the coordination in these complexes. It is known that if the coordination takes place through carboxyl oxygen it is expected that the $\mathrm{C}=\mathrm{O}$ vibration shifts strongly it has been found that the ligands with an sp2-hybridized $\mathrm{N}$ atom adjacent to the chelating $\mathrm{N}$ atom, such as phenylphthalazine derivatives, are beneficial for the metal complexes due to the shorter bond length and the stronger bonding strength between the chelating $\mathrm{N}$ atom and the metal atom, compared with analogues which have a $\mathrm{C}$ atom instead of the non-chelating $\mathrm{N}$ atom ${ }^{21-23}$.

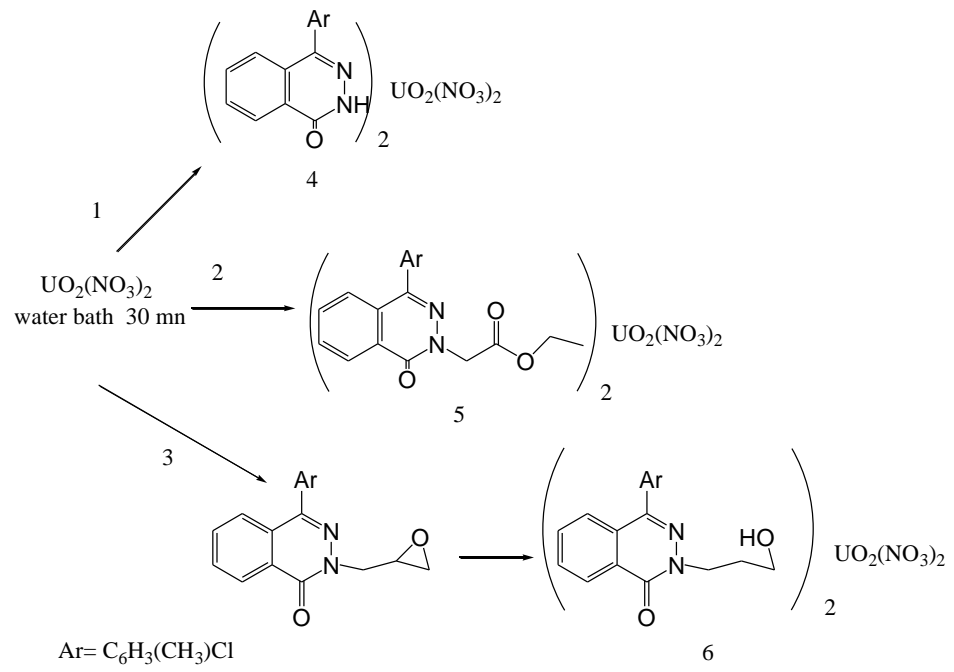

Scheme 1

the synthesis of organic ligand 4-( 3-chloro-4-methylphenyl)phthalazin-1(2H)-one 1, ethyl 2-(4-(3-chloro-4methylphenyl)-1-oxophthalazin-2(1H)-yl)acetate $\quad \mathbf{2}$ and 4-(3-chloro-4-methylphenyl)-2((oxiranyl)methyl)phthalazin-1 $(2 \mathrm{H})$-one 3 was of $1(2 \mathrm{H})$-phthalazinones molecule were separately dissolved in the of acetic acid then diluted by chloroform and of uranyl nitrate were separately dissolved in the of distilled water the uranyl nitrate transfer from the aqueous phase to the organic phase. Then, the solution of uranyl nitrate solution was added to the $1(2 \mathrm{H})$-phthalazinone solution. The mixtures were stirred together in water bath for $30 \mathrm{~min}$. The organic complex was separated by chloroform dried at room temperature, then washed with the ethanol.

the complex with 4-( 3-chloro-4-methylphenyl)-1-(2H)-phthalazinones 1 was accepted to form $\mathrm{Uo}_{2}$ [4-( 3-chloro-4methylphenyl)-1- $(2 \mathrm{H})$-phthalazinones $]_{2}$. $\left(\mathrm{NO}_{3}\right)_{2} \quad 4$.and (4-(3-chloro-4-methylphenyl)-1-oxophthalazin-2(1H)yl)acetate 2 form $\mathrm{Uo}_{2}$ [4-(3-chloro-4-methylphenyl)-1-oxophthalazin-2(1H)-yl)acetate $]_{2}$. $\left(\mathrm{NO}_{3}\right)_{2} \mathbf{5}$ (scheme 1), In the area of high frequency region the frequency shift on $\mathrm{C}-\mathrm{H}$ stretching bands of metal complexes relative to free $1(2 \mathrm{H})$ phthalazinone indicate the coordination between $1(2 \mathrm{H})$-phthalazinone and metals $\mathrm{C}-\mathrm{H}$ stretching bands of aromatic compounds are usually observed in the range usually arise below $3000 \mathrm{~cm}^{-1}$ that was indicated in the IR for the both complex 4 and 5 fig1 and fig $\mathbf{2}$ other frequency shifts in high frequency region so overtone and combination bands were observed, The $\mathrm{C}=\mathrm{O}$ strecthing bands of pyridine derivatives containing carboxyl group are usually expected to be higher than $1650 \mathrm{~cm}^{-1}$. A strong band at $1656 \mathrm{~cm}^{-1}$ in the IR spectrum of free $1(2 \mathrm{H})$-phthalazinone 1 can be assigned to $\mathrm{C}=\mathrm{O}$ stretching mode this band was observed at $1660 \mathrm{~cm}^{-1}$ in the infrared spectra of 4 (fig 1).

strong band at $1654 \mathrm{~cm}^{-1}$ in the IR spectrum of free ligand 2 can be assigned to $\mathrm{C}=\mathrm{O}$ stretching mode this band was observed at $1654 \mathrm{~cm}^{-1}$ in the infrared spectra of $\mathrm{UO}_{2}$ (phthalazinone2)n. $\left(\mathrm{NO}_{3}\right)_{2}$ but observed at $1657 \mathrm{~cm}^{-1}$ fig 2 in the IR These significant shifts in the spectra of metal complexes can be a result of The stretching frequency for $\mathrm{C}=\mathrm{O}$ increase in wavelength These significant shifts in the spectra of metal complexes can be a result of coordination taken place through the carboxyl oxygen to the metal atoms. 

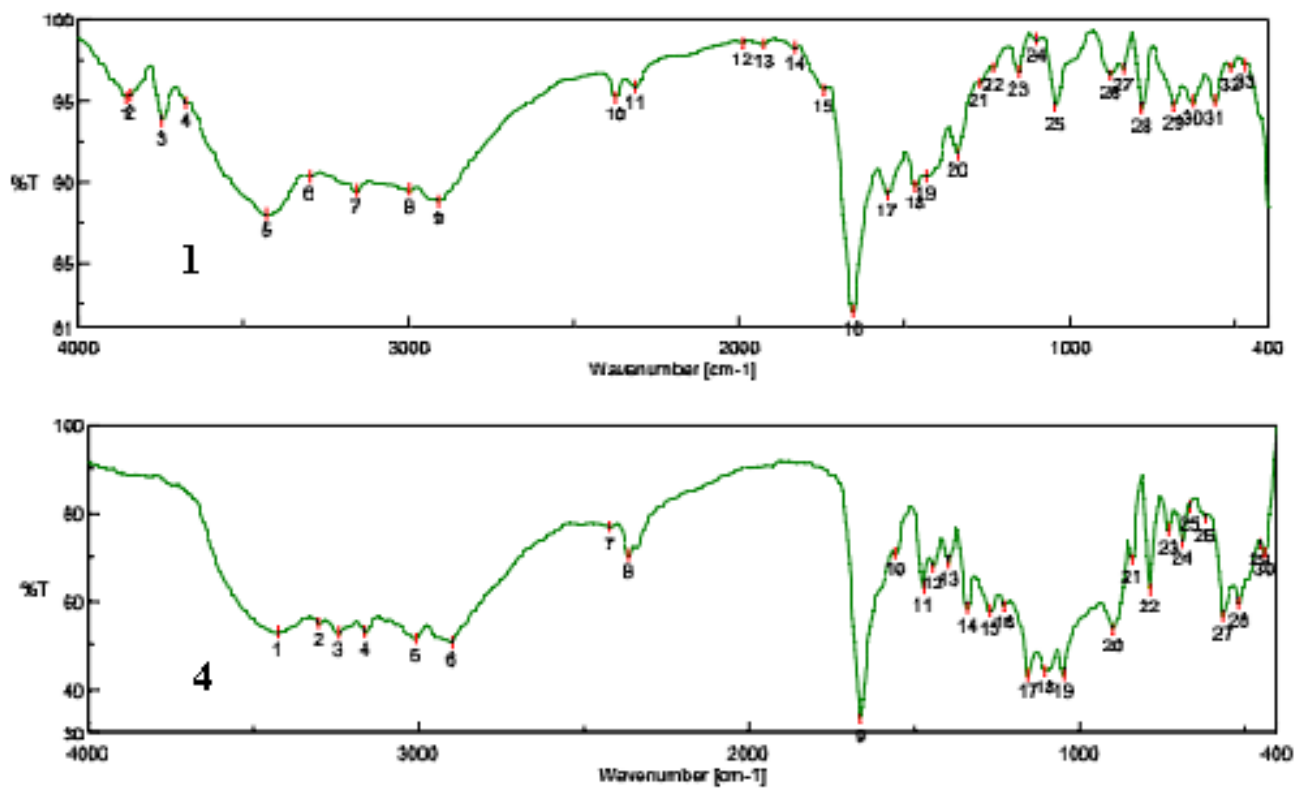

Fig 1
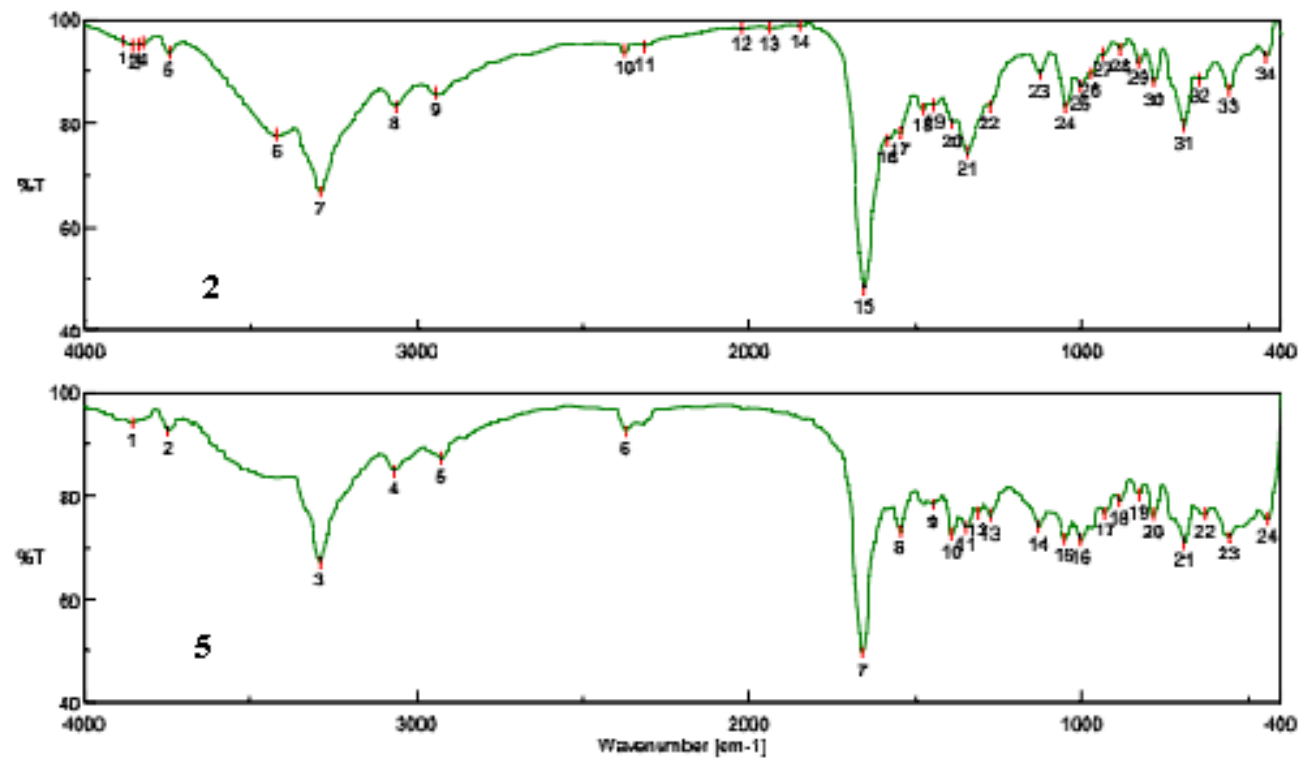

Fig 2

On the other hand $\mathrm{C}=\mathrm{C}$ and $\mathrm{C}=\mathrm{N}$ double bond stretching bands in the range $1650-1450 \mathrm{~cm}^{-1}$ the bands of 1 were observed at the intervals $1554-1436 \mathrm{~cm}^{-1}$ shifted $1556-1440 \mathrm{~cm}^{-1}$ and for 2 IR the shift from and $1582-1442 \mathrm{~cm}^{-1}$ and 1554-1446 $\mathrm{cm}^{-1}$. 4-(3-chloro-4-methylphenyl)-2((oxiran-yl)methyl)phthalazin-1(2H)-one 3 in same condition is form $\mathrm{Uo}_{2}$ (2-(3-hydroxypropyl)-4-methylphthalazin-1(2H)-one $)_{1}$. $\left(\mathrm{NO}_{3}\right)_{2} 6$ that changed in the ligand has been detriment by $\mathrm{H}^{1} \mathrm{NMR}($ scheme 1$)$.

Anticancer activity was is studded on liver hepatocellular carcinoma by Treatment of HEPG-2 with different concentrations of complex and ligand to differentiation in resulted of inhibition of the growth by different values table $\mathbf{1}$, can deduce that the presence of the uranium metal in the complex, the highest activity was given by metal complex $5 \mathrm{IC}_{50}=48 \mathrm{ug} / \mathrm{ml}$ advanced than the ligand itself according to the urinal nitrate complex see more in 
Figures 3 and 5. But the other molecule there is no any cytotoxicity had been observed in the complex based on the uranium in uranyl nitrate complex.
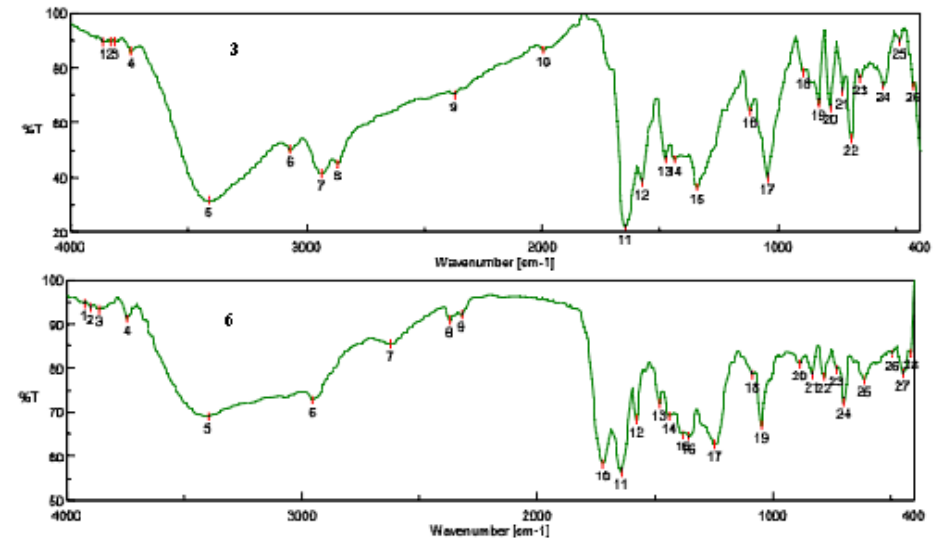

Fig 3

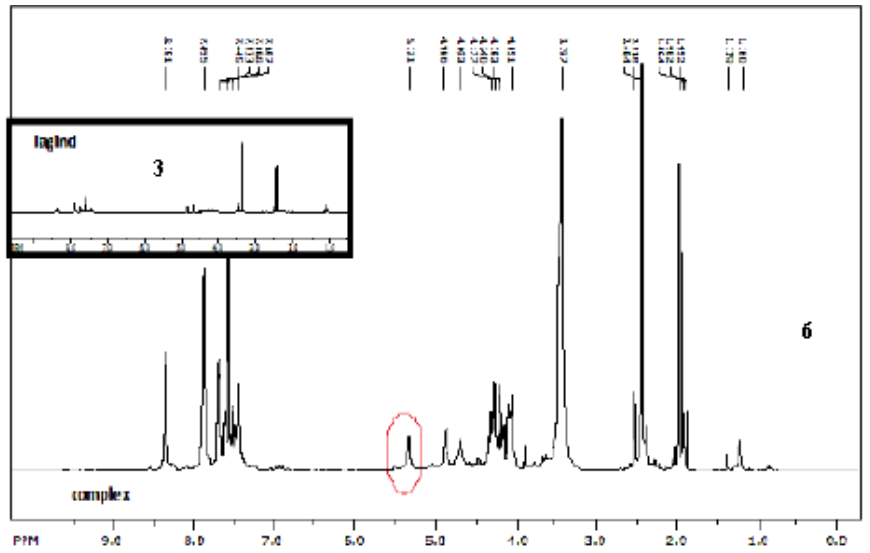

Fig 4

\begin{tabular}{ccccccc}
\hline $\begin{array}{c}\text { conc } \\
\text { ug/ml }\end{array}$ & \multicolumn{7}{c}{ compound } \\
\hline \hline & 1 & 2 & 3 & 4 & 5 & 6 \\
\hline \hline 0 & 1 & 1 & 1 & 1 & 1 & 1 \\
\hline \hline 12.5 & 0.97 & 0.913 & 0.681 & 0.924 & 0.875 & 0.692 \\
\hline \hline 25 & 0.837 & 0.76 & 0.475 & 0.837 & 0.688 & 0.646 \\
\hline \hline 50 & 0.711 & 0.593 & 0.373 & 0.684 & 0.487 & 0.673 \\
\hline \hline 100 & 0.0646 & 0.574 & 0.456 & 0.646 & 0.521 & 0.875 \\
\hline
\end{tabular}

Fig. 5: outline decrease of uranium ions by phthalazinone

Table 1

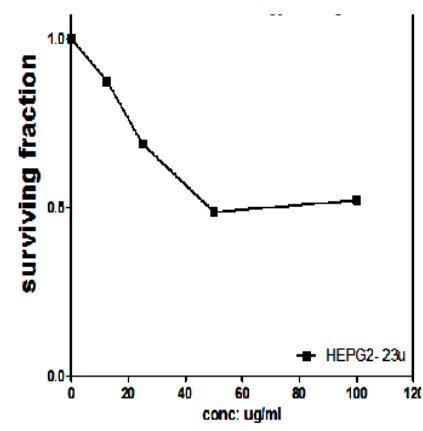




\section{Experimental:-}

Stranded solution is $1000 \mathrm{ppm}$ of uranyl nitrate was prepared by dissolving $3.13 \mathrm{mg}$ of $\left\{\mathrm{UO}_{2}\left(\mathrm{NO}_{3}\right)_{2} 6 \mathrm{H}_{2} \mathrm{O}\right\}$ Molecular Weight 502.13 in $100 \mathrm{ml}$ distilled water these solution was diluted to $100 \mathrm{ppm}, 1 \mathrm{gm} 1(2 \mathrm{H})$ phthalazinones molecule were separately dissolved in the of $10 \mathrm{ml}$ acetic acid then diluted by chloroform up to $50 \mathrm{ml}$ then solution of $100 \mathrm{ppm}$ uranyl nitrate were separately dissolved in the of distilled water. Then the solution of uranyl nitrate solution was added to the $1(2 \mathrm{H})$-phthalazinone solution. The mixtures were stirred together in water bath for $30 \mathrm{~min}$. The organic complex was separated by chloroform dried at room temperature, then washed with the ethanol.

\section{Elemental Analysis:-}

The prepared compounds, $\left[\mathrm{M}\left(1\right.\right.$ (phthalazinone)n. $\left.\left(\mathrm{NO}_{3}\right)_{2}\right]\left(\mathrm{M}=\mathrm{UO}_{2}\right)$, Elemental analyses were carried out at the Micro analytical Center, National Research Center, Cairo university, Giza, Egypt .

with the following results (found \% / calculated \%).

$5 \mathrm{UO}_{2}$ (phthalazinone1) $\left(\mathrm{NO}_{3}\right)_{2} ; \mathrm{C}: 38.54 / 39.06, \mathrm{H}: 5.58 / 4.39, \mathrm{~N}: 5.99 / 5.02$

$6 \mathrm{UO}_{2}$ (phthalazinone2) ${ }_{2}\left(\mathrm{NO}_{3}\right)_{2} ; \mathrm{C}: 41.22 / 40.25, \mathrm{H}: 3.34 / 3.47, \mathrm{~N}: 8.67 / 8.89$

$7 \mathrm{UO}_{2}$ (phthalazinone3) ${ }_{1}\left(\mathrm{NO}_{3}\right)_{2} ; \mathrm{C}: 30 / 33.39, \mathrm{H}: 2.08 / 2.67, \mathrm{~N}: 7.77 / 14.95$

\section{IR and Micro-Raman Spectroscopy:-}

IR spectra ( $\mathrm{KBr}$ disc) were recorded on infrared spectrometer FT-IR 400D (Perkin-Elmer ) spectrophotometer. Microanalytical Center,National Research Center, Cairo university, Giza, Egypt.

\section{Nuclear magnetic resonance:-}

Bruker's high-performance digital FT- NMR spectrometer $400 \mathrm{MHz}$. faculty of pharmacy cairo university, Giza, Egypt.

\section{In Vitro Cytotoxicity:-}

Effect on the Growth of Human Cancer Cell Lines The heterocyclic compounds and complex prepared in this study, were evaluated according to standard protocols for their in vitro cytotoxicity against six human cancer cell lines including cells derived from hu), human liver cancer obtained from National Cancer Institute, Cairo University under standed protocal in Cancer Biology Department

\section{4-(3-chloro-4-methylphenyl)phthalazin-1(2H)-one (1):-}

Hydrazine hydrate $(0.015 \mathrm{~mol})$ was added to a solution of 3-chloro-4-methylphenyl benzoic acid $(0.01 \mathrm{~mol})$ in absolute ethanol and the reaction mixture was heated under refluxed for $3 \mathrm{~h}$. The solid that separated after cooling was filtered off and recrystallized from ethanol to give the phthalazinon $2,80 \%$ yield as colorless crystals, m.p. 220-222 ${ }^{\circ}$; The ${ }^{1} \mathrm{H}-\mathrm{NMR}$ spectrum showed signal at 2.35 (methyl group ), $7.3-7.7(\mathrm{~m}, 7 \mathrm{H}, \mathrm{ArH}), 10.5(\mathrm{~s}, 1 \mathrm{H}$, $\mathrm{NH}$, exchangeable with $\left.\mathrm{D}_{2} \mathrm{O}\right)$. IR $(\mathrm{KBr}) v: 3296(\mathrm{NH}), 1656(\mathrm{C}=\mathrm{O}), 1554(\mathrm{C}=\mathrm{N}) \mathrm{cm}^{-1}$. EIMS $(70 \mathrm{eV}) \mathrm{m} / z(\%)$ : $276\left(\mathrm{M}^{+}, 100\right), 248(43), 220(15), 131(25), 105(15)$.Anal calcd for $\mathrm{C}_{15} \mathrm{H}_{11} \mathrm{~N}_{2} \mathrm{O} \mathrm{Cl}: \mathrm{C}, 66.66 ; \mathrm{H}, 4.07 ; \mathrm{N}$ 10.37 ; found $\mathrm{C}, 66.45 ; \mathrm{H} 4.02 ; \mathrm{N} 10.12$.

\section{Ethyl2-(1-oxo-4-( 3-chloro-4-methylphenyl)phthalazine-2(1H)-yl)acetate (2):-}

A mixture of compound $1(0.01 \mathrm{~mol}), 5 \mathrm{~mL}$ ethylbromoacetate, and $4.1 \mathrm{~g}$ anhydrous $\mathrm{K}_{2} \mathrm{CO}_{3}(0.03 \mathrm{~mol})$ in dry acetone $(30 \mathrm{~mL})$ was heated under reflux for $24 \mathrm{~h}$. The solvent was evaporated and the residue was diluted with water, the solid obtained was filtered off, dried and crystallized from pet.ether $\left(80-100^{\circ} \mathrm{C}\right)$. Yield $84 \%$ as white crystals. m.p. 110-112 ${ }^{\circ} \mathrm{C} .{ }^{1} \mathrm{H}-\mathrm{NMR}$ (DMSO-d $\left.6,300 \mathrm{MHz}\right) \delta: 2.43\left(\mathrm{t}, \mathrm{J}=7.2 \mathrm{H}_{\mathrm{Z}}, 3 \mathrm{H}, \mathrm{CH}_{2} \mathrm{CH}_{3}\right.$ ), 4.29 (q, J= $7.5 \mathrm{H}_{\mathrm{Z}}$, $\left.2 \mathrm{H}, \mathrm{OCH}_{2} \mathrm{CH}_{3}\right), 5.3\left(\mathrm{~s}, 2 \mathrm{H}, \mathrm{CH}_{2}\right), 7.3-7.7(\mathrm{~m}, 8 \mathrm{H}, \mathrm{Ar}-\mathrm{H})$. IR $(\mathrm{KBr}) v: 1750,1654(\mathrm{C}=\mathrm{O}), 1582(\mathrm{C}=\mathrm{N}) \mathrm{cm}^{-1}$. EIMS (70 eV) $m / z(\%): 362\left(\mathrm{M}^{+}, 78\right), 290(100), 134(22), 77$ (39). Anal calcd for $\mathrm{C}_{19} \mathrm{H}_{18} \mathrm{~N}_{2} \mathrm{O}_{3} \mathrm{Cl}: \mathrm{C}, 64.04 ; \mathrm{H}$, $5.05 ; \mathrm{N}, 7.86$; found $\mathrm{C}, 64.01 ; \mathrm{H}, 5.01 ; \mathrm{N}, 7.66$.

4-(3-chloro-4-methylphenyl)-2-((oxiran-2-yl)methyl)phthalazin-1(2H)-one (3):-

A mixture of compound $1(0.01 \mathrm{~mol}), 5 \mathrm{~mL}$ epichlorohydrin, and $4.1 \mathrm{~g}$ anhydrous $\mathrm{K}_{2} \mathrm{CO}_{3}(0.03 \mathrm{~mol})$ in dry acetone $(30 \mathrm{~mL})$ was heated under reflux for $24 \mathrm{~h}$. The solvent was evaporated and the residue was diluted with water, the solid obtained was filtered off, dried and crystallized from pet.ether $\left(80-100^{\circ} \mathrm{C}\right)$. Yield $64 \%$ as yellow crystals. m.p. 120-122 ${ }^{\circ} \mathrm{C} .{ }^{1} \mathrm{H}-\mathrm{NMR}\left(\mathrm{DMSO}_{6}, 300 \mathrm{MHz}\right) \delta: 2.51\left(\mathrm{t}, \mathrm{J}=7.2 \mathrm{H}_{\mathrm{Z}}, 3 \mathrm{H}, \mathrm{CH}_{2} \mathrm{CH}_{3}\right), 3.4\left(\mathrm{q}, \mathrm{J}=7.5 \mathrm{H}_{\mathrm{Z}}, 2 \mathrm{H}, \mathrm{OCHCH}_{2}\right)$, IR (KBr) $v: 1648(\mathrm{C}=\mathrm{O}), 1576(\mathrm{C}=\mathrm{N}) \mathrm{cm}^{-1}$. EIMS (70 eV) $\mathrm{m} / z(\%): 362\left(\mathrm{M}^{+}, 78\right), 290$ (100), 134 (22), 77 (39). Anal calcd for $\mathrm{C}_{19} \mathrm{H}_{18} \mathrm{~N}_{2} \mathrm{O}_{3} \mathrm{Cl}$ : C , $64.04 ; \mathrm{H}, 5.05 ; \mathrm{N}, 7.86$; found $\mathrm{C}, 64.01 ; \mathrm{H}, 5.01 ; \mathrm{N}, 7.66$. 
$\mathrm{UO}_{2}$ (4-(3-chloro-4-methylphenyl)phthalazin-1(2H)-one $)_{2}\left(\mathrm{NO}_{3}\right)_{2} 4$ :-

A mixture of compound $11 \mathrm{gm}$ 4-(3-chloro-4-methylphenyl)phthalazin-1(2H)-one, separately dissolved in the 10 $\mathrm{ml}$ of acetic acid then diluted by chloroform up to $50 \mathrm{ml}$ Stranded solution $100 \mathrm{ppm}$ of uranyl nitrate $\left(\mathrm{UO}_{2}\left(\mathrm{NO}_{3}\right)_{2} 6 \mathrm{H}_{2} \mathrm{O}\right)$ were separately dissolved added 1:1 volume of of uranyl nitrate solution was added to the $\mathbf{1}$ The mixtures were stirred together in water bath for $30 \mathrm{~min}$ the organic layer are separated by separation vinyl The solvent was evaporated and the residue was washed by distilled water and ethanol , the solid obtained. Yield 100\% as yellow crystals. ${ }^{1} \mathrm{H}-\mathrm{NMR}\left(\mathrm{DMSO}_{6}, 300 \mathrm{MHz}\right) \delta: 1.9\left(\mathrm{t}, \mathrm{J}=7.2 \mathrm{H}_{\mathrm{Z}}, 3 \mathrm{H}_{1}, \mathrm{CH}_{3}\right.$ ) shifted to High FieldRegion $4 \mathrm{ppm}$, $12.88(, \mathrm{NH})$ shifted $.01 \mathrm{ppm}, \mathrm{IR}(\mathrm{KBr}) v: 1656(\mathrm{C}=\mathrm{O}), 1554(\mathrm{C}=\mathrm{N}) \mathrm{cm}^{-1}$.

\section{$\mathrm{UO}_{2}$ (Ethyl2-(1-oxo-4-( 3-chloro-4-methylphenyl)phthalazine-2(1H)-yl)acetate $)_{2}\left(\mathrm{NO}_{3}\right)_{2}$ 5:-}

A mixture of compound 2 1gm Ethyl2-(1-oxo-4-( 3-chloro-4-methylphenyl)phthalazine-2(1H)-yl)acetate, separately dissolved in the $10 \mathrm{ml}$ of acetic acid then diluted by chloroform up to 50ml Stranded solution 100ppm of uranyl nitrate $\left(\mathrm{UO}_{2}\left(\mathrm{NO}_{3}\right)_{2} 6 \mathrm{H}_{2} \mathrm{O}\right)$ were separately dissolved added 1:1 volume of of uranyl nitrate solution was added to the The mixtures were stirred together in water bath for $30 \mathrm{~min}$ the organic layer are separated by separation vinyl The solvent was evaporated and the residue was washed by distilled water and ethanol, the solid obtained. Yield $100 \%$ as yellow crystals. ${ }^{1} \mathrm{H}-\mathrm{NMR}\left(\mathrm{DMSO}-\mathrm{d}_{6}, 300 \mathrm{MHz}\right)$

$\delta: 1.75\left(\mathrm{t}, \mathrm{J}=7.2 \mathrm{H}_{\mathrm{Z}}, 3 \mathrm{H}, \mathrm{CH}_{2} \mathrm{CH}_{3}\right)$ shifted $.55 \mathrm{ppm}, 4.29\left(\mathrm{q}, \mathrm{J}=7.5 \mathrm{H}_{\mathrm{Z}}, 2 \mathrm{H}, \mathrm{OCH}_{2} \mathrm{CH}_{3}\right), 5.3\left(\mathrm{~s}, 2 \mathrm{H}, \mathrm{CH}_{2}\right), 7.3-7.7(\mathrm{~m}$ , 8H , Ar-H). IR (KBr) $v: 1657(\mathrm{C}=\mathrm{O}), 1545(\mathrm{C}=\mathrm{N}) \mathrm{cm}^{-1}$

\section{Uo2(2-(3-hydroxypropyl)-4-methylphthalazin-1(2H)-one) ${ }_{1}\left(\mathrm{NO}_{3}\right)_{2:-}$}

A mixture of compound $31 \mathrm{gm}$ 4-(3-chloro-4-methylphenyl)-2-((oxiran-2-yl)methyl)phthalazin-1(2H)-one, separately dissolved in the $10 \mathrm{ml}$ of acetic acid then diluted by chloroform up to $50 \mathrm{ml}$ Stranded solution 100ppm of uranyl nitrate $\left(\mathrm{UO}_{2}\left(\mathrm{NO}_{3}\right)_{2} 6 \mathrm{H}_{2} \mathrm{O}\right)$ were separately dissolved added 1:1 volume of of uranyl nitrate solution was added to the The mixtures were stirred together in water bath for $30 \mathrm{~min}$ the organic layer are separated by separation vinyl The solvent was evaporated and the residue was washed by distilled water and ethanol, the solid obtained. Yield $100 \%$ as yellow crystals. ${ }^{1} \mathrm{H}-\mathrm{NMR}\left(\mathrm{DMSO}_{6} \mathrm{~d}_{6}, 300 \mathrm{MHz}\right) \quad \delta: 1.75$ (t, J= $7.2 \mathrm{H}_{\mathrm{Z}}, 3 \mathrm{H}, \mathrm{CH}_{2} \mathrm{CH}_{3}$ ) shifted .55 ppm, 1.84 (q, J= $\left.7.5 \mathrm{H}_{\mathrm{Z}}, 2 \mathrm{H}, \mathrm{CH}_{2} \mathrm{CH}_{2} \mathrm{CH}_{2} \mathrm{OH}\right), 3.88$ (s, $\left.2 \mathrm{H}, \mathrm{CH}_{2} \mathrm{CH}_{2} \mathrm{CH}_{2} \mathrm{OH}\right), 4.87$ (s, $2 \mathrm{H}, \mathrm{CH}_{2} \mathrm{CH}_{2} \mathrm{CH}_{2}$ $\mathrm{OH}), 1.96(\mathrm{OH}), 7.3-7.7(\mathrm{~m}, 3 \mathrm{H}, \mathrm{Ar}-\mathrm{H})$. IR $(\mathrm{KBr}) v: 1644(\mathrm{C}=\mathrm{O}), 1578(\mathrm{C}=\mathrm{N}) \mathrm{cm}$.

\section{References:-}

1. A.B.p.lever.j.Lewis and R.S.Nyholm,J.chem.Soc.1235(1962).

2. A.B.p.lever.j.Lewis and R.S.Nyholm,J.chem.Soc.3156(1963).

3. A.B.p.lever.j.Lewis and R.S.Nyholm,J.chem.Soc.5042(1963).

4. A.B.p.lever.j.Lewis and R.S.Nyholm,J.chem.Soc.4761(1964).

5. J. R.Allan.G. A. Brarnes ,D. H. Brown., J .inorg. nuci.1971,Vol.33,pp.3765-3771.

6. L.D. Popov, S.I. Levchenkov, I.N. Shcherbakov, V.A. Kogan, Yu.P. Tupolova, 2010, published in Zhurnal Obshchei Khimii, 2010, Vol. 80, No. 3, pp. 471-478.

7. Seema Srivastava, Om P. Pandey and Soumitra K. Sengupta Transition Met. Chem., 21,262 265 (1996).

8. Stefan Roggan, Christian Limberg, Christina Knispela and T. Don Tilley, Dalton Trans., 2011, 40, 4315-4323| 4315

9. V. A. Kogan, S. I. Levchenkov ,L. D. Popov , and I. A. Shcherbakov Russian Journal of General Chemistry, 2009, Vol. 79, No. 12, pp. 2767-2775.

10. Bao Xiu Mi, Peng Fei Wang, Zhi Qiang Gao, Chun Sing Lee, Shuit Tong Lee, Hui Ling Hong, Xiao Ming Chen, Man Shing Wong, Ping Fang Xia, Kok Wai Cheah, Chin Hsin Chen and Wei Huang Adv. Mater. 2009, 21, 339-343.

11. Yuan Fang, Sujun Hu, Yuezhong Meng, Junbiao Peng, Biao Wang ,Inorganica Chimica Acta 362 (2009) 4985-4990

12. Thomas D. Anthopoulos, Michael J. Frampton, Ebinazar B. Namads, Paul L. Burn and Ifor D. W. Samuel . Adv. Mater. 2004, 16, No. 6, March 18 .

13. Bi-Hai Tong, Fang-Hui Wu, Qun-Bo Mei, and Qian-Feng Zhang. Z. Naturforsch. 2010, 65b, $511-515$.

14. Z. Q. Gao, B. X. Mi, H. L. Tam, K. W. Cheah, C. H. Chen, M. S. Wong,S. T. Lee,C. S. Lee Adv. Mater. 2008, 20,774-778.

15. Bi-hai Tong, Qunbo Mei, Shuanjin Wang, Yuan Fang, Yuezhong Meng and Biao Wang J. Mater. Chem., 2008, $18,1636-1639$.

16. Kuzelka, J.;Spingler, B.;Lippard, S. J. Inorg. Chim.acta 2002,337,212-222.

17. Barrios, A.M.; Lippard, S. J. Inorg. Chem. 2001,40,1060-1064. 
18. Barrios, A.M.; Lippard, S. J. Inorg. Chem.2001,40,1250-1255.

19. Barrios, A.M.; Lippard, S. J. J. Am. Chem. Soc. 2000,9172-9177.

20. Barrios, A.M.; Lippard, S. J. J. Am. Chem. Soc. 1999,121,11751-11757.

21. Z. Q. Gao, B. X. Mi, H.L. Tam, Adv. Mater. 2008, 20, $774-778$.

22. N. Öztürk1, S. Bahçeli1 SDU Journal of Science (E-Journal), 2012, 7 (1): 1-8

23. D. Reed and M. A. Duncan J Am Soc Mass Spectrom 2010, 21, $739-749$

24. M. Kurt, S . Yurdakul / Journal of Molecular Structure: THEOCHEM 717 (2005) 171-178.

25. Silverstein, R.M., Webster, F.X., 1998. Spectroscopic Identification of Organic Compound, 6th ed. John Wiley \& Sons, New York, p. 512.

26. S. Ghammamy, M. K. Mohammadi ,Z. Amini, M. A. Mirrahimia, M. Soleimani and S. Kaviani International Journal of Heterocyclic Chemistry, Vol. 1, No. 1

27. S. Ghammamy and S. Sedaghat Middle-East J. Sci. Res., 11 (7): 908-914, 2012

28. S. GHAMMAMY and S. SEDAGHAT, Mat. Sci. Res. India, Vol. 9(2), 173-178 (2012)

29. I. M. Gabr , H. A. El-Asmy , M. S. Emmam , S. I. Mostafa Transition Met Chem (2009) 34:409-418 